\section{Effects of Morning and Afternoon Shade in Combination with Traffic Stress on Seashore Paspalum}

\author{
Yiwei Jiang ${ }^{1}$, Robert N. Carrow ${ }^{2}$, and Ronny R. Duncan ${ }^{2}$ \\ Department of Crop and Soil Sciences, Georgia Experiment Station, University \\ of Georgia, Griffin, GA 30223-1797
}

Additional index words. Paspalum vaginatum, turfgrass, wear, wear plus soil compaction

\begin{abstract}
Turfgrasses are often exposed to different shade environments in conjunction with traffic stresses (wear and/or compaction) in athletic fields within stadiums. The objective of this study was to assess the effects of morning shade (AMS) and afternoon shade (PMS) alone and in combination with wear and wear plus soil compaction on 'Sea Isle 1' seashore paspalum (Paspalum vaginatum Swartz). The study was conducted using two consecutive field trials under sports field conditions from 9 July to 10 Sept. 2001 at the Univ. of Georgia Experiment Station at Griffin. "T" shaped structures constructed of plywood on the sports field were used to provide $\approx 90 \%$ morning and afternoon shade, respectively, and were in place for 1 year prior to data accumulation. A wear device and a studded roller device simulated turfgrass wear (WD) and wear plus soil compaction (WSC), respectively, to the shaded plots. Only minor differences in turf color, density, or canopy spectral reflectance were found between AMS and PMS under no-traffic treatments in both trials. Grasses under WD generally recovered faster than those exposed to WSC across all light levels, including full sunlight (FL), AMS, and PMS. AMS combined with WD treatment had an average $9 \%$ higher rating of color, $11 \%$ higher density, and $28 \%$ less tissue injury than that of PMS with WD at 7 days after traffic treatment (DAT). Compared to PMS with WSC treatment at 7 DAT, AMS with WSC had $12 \%$ higher rating of color, $9 \%$ higher density, and $4 \%$ less tissue injury. AMS with WD treatment exhibited $11 \%$ higher normalized difference vegetation index (NDVI), 4\% higher canopy water band index (CWBI), and 13\% lower stress index than that of PMS with WD at 7 DAT. AMS with WSC, relative to PMS with WSC, demonstrated $8 \%$ higher NDVI, $3 \%$ higher CWBI, and $8 \%$ lower stress index at 7 DAT. Results indicated that AMS (i.e., afternoon sunlight) had less detrimental influences than PMS (i.e., morning sunlight) on turfgrass performance after it was subjected to wear stress or wear plus soil compaction.
\end{abstract}

Turfgrasses are often exposed to shade environments, and shade stress is one of the major problems limiting turfgrass growth. Physiological and growth responses associated with shade tolerance have been investigated in a number of turfgrass species (Bell and Danneberger, 1999; Qian and Engelke, 1999; Stier and Rogers, 2001; Van Huylenbroeck and Van Blockstaele, 2001). In many recreational sites, light is available for turfgrass only during morning or afternoon hours because of restricted light intensities from trees or stadium structures. However, no variations in growth of creeping bentgrass (Agrostis palustris Huds.) was found between morning and afternoon shade or between plots in $80 \%$ or $100 \%$ shade under shadecloth (Bell and Danneberger, 1999). Their results also showed that turf color and density did not vary between creeping bentgrass exposed to morning shade, afternoon shade, or full sunlight, but continuous shade caused severe decline in turfgrass growth and development.

Along with shade, traffic is another factor that is often considered to be one of the

Received for publication 8 July 2002. Accepted for publication 4 Feb. 2003.

${ }^{1}$ Postdoctoral Research Associate. E-mail: yjiang@ griffin.uga.edu

${ }^{2}$ Professor. primary stresses on sports fields. It is vital to evaluate turfgrass tolerance to traffic stress due to high use demands placed on recreational grasses. Traffic generally consists of turfgrass wear stress and soil compaction (Carrow and Petrovic, 1992). Several independent studies have been reported on wear tolerance (Canaway et al., 1981; Carrow and Johnson, 1996; Shearman and Beard, 1975; Trenholm et al., 1999 b) and soil compaction in turfgrass (Carrow, 1980). Wear and soil compaction stresses usually both occur on athletic fields and result in more severe injury to turfgrass; however, few studies have investigated these two factors simultaneously. More recently, turfgrass traffic simulators have been designed primarily to apply wear only or wear plus soil compaction to turfgrass and to evaluate turfgrass performance, including seashore paspalum and bermudagrass (Cynodon sp.) (Carrow et al., 2001), Kentucky bluegrass (Poa pratensis L.) (Shearman et al., 2001), and bermudagrass (Cynodon dactylon L.) with cool-season turfgrass mixtures (Dunn et al., 1994).

Turfgrass injury could be greater under the combined stresses of shade and traffic in comparison to either stress alone. The additive effects of these stresses make turfgrass management more difficult, particularly for sports fields. Turfgrass grown under reduced irradiance is easily damaged from traffic (Cock- erham et al., 1994) because shade environments alter turfgrass morphological, physiological, and anatomical responses, causing excessive shoot elongation and reduced shoot density (Beard, 1997). Under low irradiance, application of trinexapac-ethyl [4-(cyclopropyl$\alpha$-hydroxy-methylene)-3,5-dioxo-cyclohexane-carboxylic acid ethyl ester] enhanced turf quality by decreasing traffic effects (Stier and Rogers, 2001). However, the combined effects of morning and afternoon shade with different traffic stresses on turfgrass quality and recoverability from injury have not been examined. Influences of shade with wear or wear plus soil compaction will have an impact on successful management of sports fields.

Seashore paspalum is an environmentally compatible warm-season turfgrass that has become adapted to a wide range of environmental conditions (Duncan, 1999). Wear tolerance of different seashore paspalum ecotypes has also been evaluated (Trenholm et al., 1999b), but not under shade conditions. 'Sea Isle 1' seashore paspalum is adapted to sports-related uses, and knowledge of temporal shade combined with traffic stresses on this grass would benefit sports turf management. Therefore, the objective of this study was to assess the effects of morning and afternoon shade alone and in combination with wear and wear plus soil compaction on 'Sea Isle 1' seashore paspalum.

\section{Materials and Methods}

Plant growth. This research consisted of two studies conducted at the Univ. of Georgia Experiment Station in Griffin. Study 1 was conducted from 9 July to 30 July 2001, and Study 2 was conducted from 20 Aug. to 10 Sept. 2001. 'Sea Isle 1' seashore paspalum was fully established on a simulated sports field since 1999 and was used in this experiment. The soil profile was an Appling sandy clay loam (clayey, kaolinitic, thermic Typic Kanhapludult) capped with a 10 -cm mixture of $90 \%$ sand and $10 \%$ peat. The plots were mowed to $1.7 \mathrm{~cm}$ three times weekly using a reel mower with clippings removed. The grasses were irrigated to $2.4 \mathrm{~cm}$ weekly. Fertilization applied to the site in terms of $\mathrm{N} \mathrm{kg} \cdot \mathrm{ha}^{-1}$ in 2001 was: $5.8 \mathrm{~N}$ on 13 Apr. $(12 \mathrm{~N}-24 \mathrm{P}-14 \mathrm{~K}) ; 16 \mathrm{~N}$ on $30 \mathrm{Apr}$. and 18 May $(34 \mathrm{~N}-0 \mathrm{P}-0 \mathrm{~K}) ; 6.6 \mathrm{~N}$ on 23 May (Milorganite, 6.75N-2.65P-0.46K, Milwaukee Metropolitan Sewerage District, Milwaukee); $9.8 \mathrm{~N}$ on 25 May, 1 June, and 10 July (GreenEdge, 10N-0P-18K, GreenTechnologies, Gainesville, Fla.); $7.3 \mathrm{~N}$ on 25 July $(15 \mathrm{~N}-0 \mathrm{P}-15 \mathrm{~K})$.

Shade environment. The shade environment was created using a "T" shaped structure constructed of plywood on the simulated sports field. Each of the three structures was $4.9 \mathrm{~m}$ long, $1.4 \mathrm{~m}$ high, had a $6.0-\mathrm{m}^{2}$ area covered horizontally with plywood on the top, and was oriented north to south. The vertical plywood under the top cover could be moved out of the structure to allow operation of the traffic devices and mowers. The "T" structure could provide an area of $15 \mathrm{~m}^{2} \mathrm{AMS}$ and $15 \mathrm{~m}^{2} \mathrm{PMS}$ from July to September. Plots of $3.2 \mathrm{~m}^{2}$ within the $15-\mathrm{m}^{2}$ shade area, receiving up to $5 \mathrm{~h}$ AMS 
or $5 \mathrm{~h}$ PMS at both beginning and end of trials in both studies, were used in the evaluation of turf performance. Irrigation and rainfall could also reach these plots, which were not affected by the horizontal roof structure. For Study 2, a new plot area was used. The control areas received full sunlight (FL) without a "T" structure. The structures were placed on the research plots during June 2000 or $\approx 1$ year before data accumulation.

Traffic stresses. The two traffic stresses, wear and wear plus soil compaction, were imposed by a wear device (primarily wear stress, WD) (Shearman et al., 2001) and a studded roller device (wear plus soil compaction, WSC) (Carrow et al., 2001), respectively. These research papers contain detailed information on each traffic device. The WD had smooth, rubber-coated rollers and applied a static pressure of $0.90 \mathrm{~kg} \cdot \mathrm{cm}^{-2}$ over the contact area, traveling at a speed of 0 to $1.8 \mathrm{~m} \cdot \mathrm{s}^{-1}$. The rear roller assembly included a $50-\mathrm{cm}$ diameter roller; the front two rollers were $99 \mathrm{~cm}$ long with a $3.8-\mathrm{cm}$ steel shaft that extended $15.2 \mathrm{~cm}$ beyond the ends of each roller. The wear device used an adjustable differential slip mode between the front and rear rollers to add tear and abrasion injury to the wear damage. It was designed primarily to impose wear stress with minimal pressure to the soil, with little soil compaction. The studded roller device (WSC) contained the largest U.S. football stud used in high schools and on the same average spacing (one stub per $40 \mathrm{~cm}^{2}$ ). The studs were $12.7 \mathrm{~mm}$ in diameter, $20 \mathrm{~mm}$ long, and welded onto the two front rollers, which had a $46-\mathrm{cm}$ diameter $\times 76 \mathrm{~cm}$ wide with a total surface of $21,877 \mathrm{~cm}^{2}$. The device could impose wear stress plus soil compaction and applied a static pressure of 0.49 $\mathrm{kg} \cdot \mathrm{cm}^{-2}$ to the grass over surface contact area of the roller, but pressure was applied at 1027 $\mathrm{kg} \cdot \mathrm{cm}^{-2}$ on the top surface area of each stud as it contacted the soil. The machine traveled at a speed of $1.35 \mathrm{~m} \cdot \mathrm{s}^{-1}$. The WD treatment consisted of 40 passes, and the WSC treatment consisted of 20 passes to approximate the same degree of shoot injury to the grasses. During application of the WD and WSC treatments, the first pass was in the forward (from east to west) and the next pass was in the reverse mode to apply traffic treatment rapidly and uniformly. After 20 passes of WD and 10 passes of WSC, the machines were turned and operated in the other direction (from west to east) for an identical number of passes to ensure uniformity of treatment across the width of the roller units as well as across the length of treated areas. The traffic treatments were selected to represent about three high school football games in the middle of the field, based on calibration with local fields under similar soils. Both sides of a "T" structure and a FLarea outside the structure received the WD and WSC.

Measurements. All ratings and measurements were made weekly, except initial data were collected $1 \mathrm{~d}$ after traffic was imposed, when the most severe shoot tissue injury was shown before any recovery. Turf color rating was on a scale of 1 to 9 , where 1 was brown color and 9 was dark green. Turf density rating was based on shoot density, where 1 was no grass and 9 was uniformly dense grass. Tissue injury was observed visually, and expressed as percentage of leaves killed or injured due to traffic stress. Light intensity was measured using a LI-250 light meter (LI-Cor, Lincoln, Nebr.) with quantum sensor to quantify photosynthetically active radiation $(P A R)$ $\left(\mu \mathrm{mol} \cdot \mathrm{s}^{-1} \cdot \mathrm{m}^{-2}\right)$ inside the shaded plots and plots under full sunlight. Canopy spectral reflectance measurements were taken with a Unispec Spectral Analysis System (PP Systems, Haverhill, Mass.), which measured reflectance from 400- to $1100-\mathrm{nm}$ wavelength with $3-\mathrm{nm}$ intervals. Reflectance foreoptics are bifurcated fiber-optics, and ambient light illuminated the canopy during measurement. The fiber-optics probe was held $20 \mathrm{~cm}$ directly aboveground and reflectance readings were taken at 1:00 PM on a sunny day when all plots did not receive any shade. Canopy reflectance was measured immediately after the white standard reference was scanned. Canopy reflectance was calculated by comparing the sample reflectance to a standard reference scan.

The following indices related to canopy status were developed based on reflectance: NDVI (normalized difference vegetation index), stress index, and CWBI (canopy water band index).

-NDVI: (R750-R705)/(R750 + R705) (Gamon and Surfus, 1999). R750 means reflectance at wavelength $750 \mathrm{~nm}$, and this is similar for other wavelength notations.

-Stress index: (R706/R813) (Trenholm et al., 1999a).

-CWBI: (R900/R970) (Penuelas et al., 1997b).

Experimental design and statistical analyses. This experiment was a randomized complete-block design with a 3 (light) $\times 3$ (traffic) factorial arrangement. The three light levels were FL, AMS, and PMS; and the three traffic treatments were no-traffic, WD, and WSC. Three replicates of " $T$ " structures were used in this study. Orthogonal paired comparisons were analyzed to compare AMS and PMS within no-traffic, WD, and WSC. The main effects of light or traffic were tested using least significance difference (LSD) at $P<$ 0.05 . Each study was analyzed separately due to a significant treatment $x$ time interaction. Analysis of variance was based on the general linear model procedure of the Statistics Analysis System (SAS, 1987) (SAS Institute Inc., Cary, N.C.).

\section{Results}

Light intensity, turfcolor, and density. Light intensities were measured during studies from July to September. In Study 1, light intensities in the shaded area that was used for evaluation of turf performance were $7 \%$ to $14 \%$ PAR of full sunlight (FL) in the morning and $6 \%$ to $17 \%$ of FL in the afternoon on a sunny day. In Study 2, light intensities were $11 \%$ to $15 \%$ and $11 \%$ to $13 \%$ of FL for morning and afternoon, respectively.

Turf color and density were significantly affected by traffic and light factors (Table 1). Across traffic stresses, grasses receiving FL had better turf color and higher density than grasses grown under AMS or PMS up to 14 DAT in both studies. However, no significant difference was observed between AMS and PMS treatments except for shoot density at 7 DAT in Study 1 when compared across traffic. Across light levels, WD and WSC traffic caused a reduction in turf color and density compared to the non-traffic treatment; while WSC treatment showed slower recovery of color and density ratings than that of WD in both studies. Strong interactions between light and traffic were found in all visual ratings except for turf color at 7 and 14 DAT in Study 1. Under no-traffic conditions, no variation in turf quality was found between AMS and PMS treatments. AMS with WD traffic resulted in better turf appearance (average 9\% higher rating of color and $11 \%$ higher density) than PMS with WD up to 7 DAT in both studies, while AMS subjected to WSC had better turf appearance (average 12\% higher rating of color and 9\% higher density) than PMS with WSC up to 14 DAT in both studies.

Shoot tissue injury. The shaded grasses showed maximum shoot injury $1 \mathrm{~d}$ following WD and WSC traffic treatments in both studies (Table 2). Initially, injured tissues showed darker leaf color, but WD increased the greasy appearance and WSC enhanced leaf browning with reduced shoot density. Across traffic stresses, AMS and PMS showed severe initial shoot injury and less recovery relative to FL in both studies. No significant difference in shoot injury was found between AMS and PMS, except at 7 DAT when PMS had more injured tissue in Study 1. Across light levels, no injury was found in grass grown under notraffic conditions and WSC treatment showed more injury and less recovery than that of WD at 14 DAT. A strong light $\times$ traffic interaction was observed for shoot injury. AMS with WD showed less tissue injury than PMS with WD at 7 DAT and 7 to 14 DAT for Studies 1 and 2 , respectively (average $28 \%$ less). AMS with WSC showed less tissue injury at 14 and 7 DAT in Studies 1 and 2, respectively (average $4 \%$ less).

Canopy spectral reflectance. Canopy spectral reflectance data were significantly affected by traffic and shade stresses (Table 3). Across traffic stresses, FL with no-traffic treatment had higher NDVI and CWBI and lower stress index to that of PMS in both studies, but similar to that of AMS except for CWBI at 14 DAT in Study 1 and at 7 DAT in Study 2. Across light levels, FL treatment had higher NDVI and CWBI and lower stress index than that of WD at 7 DAT in both studies and than that of WSC up to 14 DAT except for stress index in Study 2. Across no-traffic, no variation was observed in these indices between AMS and PMS except for 14 DAT in Study 2, when AMS had higher NDVI, CWBI, and lower stress index than that of PMS.

As with turf color and density, canopy reflectance indices exhibited a traffic $\times$ light interaction on most dates (Table 3 ). WD with AMS had higher NDVI and CWBI at 7 DAT in Study 1 and higher NDVI, CWBI, and lower stress index at 7 and 14DAT in Study 2 than that 
Turf MANAgement

Table 1. Turf color and density affected by shade and traffic stresses during Studies 1 and 2.

\begin{tabular}{|c|c|c|c|c|c|c|c|c|c|c|c|c|}
\hline \multirow[b]{3}{*}{ Treatments/Contrasts } & \multicolumn{6}{|c|}{ Study 1} & \multicolumn{6}{|c|}{ Study 2} \\
\hline & \multicolumn{3}{|c|}{ Color } & \multicolumn{3}{|c|}{ Density } & \multicolumn{3}{|c|}{ Color } & \multicolumn{3}{|c|}{ Density } \\
\hline & $1 \mathrm{DAT}^{\mathrm{z}}$ & 7 DAT & $14 \mathrm{DAT}$ & $1 \mathrm{DAT}$ & 7 DAT & 14 DAT & $1 \mathrm{DAT}$ & 7 DAT & 14 DAT & $1 \mathrm{DAT}$ & 7 DAT & 14 DAT \\
\hline$\overline{\text { FL, no-traffic (control) }}{ }^{y}$ & 8.2 & 8.1 & 8.1 & 8.2 & 8.2 & 8.1 & 8.2 & 8.1 & 8.1 & 8.2 & 8.1 & 8.1 \\
\hline \multicolumn{13}{|c|}{ Mean separation ${ }^{x}$} \\
\hline Across traffic & & & & & & & & & & & & \\
\hline FL & $6.5 \mathrm{a}^{\mathrm{w}}$ & $7.2 \mathrm{a}$ & $7.8 \mathrm{a}$ & $6.4 \mathrm{a}$ & $6.9 \mathrm{a}$ & $7.6 \mathrm{a}$ & $6.7 \mathrm{a}$ & $7.3 \mathrm{a}$ & $7.9 \mathrm{a}$ & $6.7 \mathrm{a}$ & $6.9 \mathrm{a}$ & $7.5 \mathrm{a}$ \\
\hline AMS & $5.6 \mathrm{~b}$ & $6.6 \mathrm{~b}$ & $7.3 \mathrm{~b}$ & $5.4 \mathrm{~b}$ & $6.1 \mathrm{~b}$ & $6.8 \mathrm{~b}$ & $6.1 \mathrm{~b}$ & $6.8 \mathrm{~b}$ & $7.4 \mathrm{~b}$ & $6.1 \mathrm{~b}$ & $6.1 \mathrm{~b}$ & $6.8 \mathrm{~b}$ \\
\hline PMS & $5.3 \mathrm{~b}$ & $6.2 \mathrm{~b}$ & $7.4 \mathrm{~b}$ & $5.3 \mathrm{~b}$ & $5.6 \mathrm{c}$ & $6.5 \mathrm{~b}$ & $5.9 \mathrm{~b}$ & $6.7 \mathrm{~b}$ & $7.3 \mathrm{~b}$ & $6.1 \mathrm{~b}$ & $6.1 \mathrm{~b}$ & $6.9 \mathrm{~b}$ \\
\hline \multicolumn{13}{|l|}{ Across light } \\
\hline Non & $8.0 \mathrm{a}$ & $8.0 \mathrm{a}$ & $7.9 \mathrm{a}$ & $8.0 \mathrm{a}$ & $7.9 \mathrm{a}$ & $7.9 \mathrm{a}$ & $8.0 \mathrm{a}$ & $7.9 \mathrm{a}$ & $7.9 \mathrm{a}$ & $8.2 \mathrm{a}$ & $7.9 \mathrm{a}$ & $7.9 \mathrm{a}$ \\
\hline WD & $4.7 \mathrm{~b}$ & $6.5 \mathrm{~b}$ & $7.6 \mathrm{~b}$ & $4.9 \mathrm{~b}$ & $5.8 \mathrm{~b}$ & $7.1 \mathrm{~b}$ & $5.1 \mathrm{~b}$ & $6.6 \mathrm{~b}$ & $7.6 \mathrm{~b}$ & $5.7 \mathrm{~b}$ & $6.1 \mathrm{~b}$ & $7.0 \mathrm{~b}$ \\
\hline WSC & $4.7 \mathrm{~b}$ & $5.5 \mathrm{c}$ & $7.0 \mathrm{c}$ & $4.2 \mathrm{c}$ & $4.9 \mathrm{c}$ & $6.1 \mathrm{c}$ & $5.6 \mathrm{c}$ & $6.2 \mathrm{c}$ & $7.1 \mathrm{c}$ & $5.0 \mathrm{c}$ & $5.2 \mathrm{c}$ & $6.5 \mathrm{c}$ \\
\hline \multicolumn{13}{|c|}{ Orthogonal comparison } \\
\hline Non + AMS & 7.9 & 7.9 & 7.9 & 7.9 & 7.8 & 7.8 & 8.0 & 7.9 & 7.8 & 8.1 & 7.8 & 7.8 \\
\hline Non + PMS & 7.9 & 7.8 & 7.8 & 7.9 & 7.8 & 7.8 & 7.9 & 7.7 & 7.7 & 8.1 & 7.7 & 7.8 \\
\hline WD + AMS & 4.8 & 6.6 & 7.4 & 4.7 & 5.8 & 6.8 & 4.9 & 6.8 & 7.4 & 5.6 & 6.0 & 6. \\
\hline WD + PMS & $4.0^{*}$ & 6.1 & 7.2 & $4.2^{*}$ & $5.0^{* *}$ & 7.0 & $4.6^{*}$ & $6.2^{* * *}$ & 7.3 & 5.4 & $5.6^{* * *}$ & 6.6 \\
\hline WSC + AMS & 4.0 & 5.5 & 6.9 & 3.7 & 4.7 & 5.7 & 5.3 & 6.1 & 6.7 & 4.4 & 5.1 & 6.4 \\
\hline WSC + PMS & 3.9 & $4.7^{*}$ & 6.5 & 3.7 & $4.3^{* *}$ & $5.0^{*}$ & 5.3 & $5.7^{*}$ & 6.8 & 4.5 & $4.7^{* * * *}$ & $6.0^{* *}$ \\
\hline \multicolumn{13}{|c|}{ Analysis of variance } \\
\hline Traffic (T) & $* * *$ & $* * *$ & **** & $* * *$ & $* * *$ & $* * *$ & $* * *$ & $* * *$ & $* * *$ & $* * *$ & $* * *$ & $* * *$ \\
\hline Light (L) & $* * *$ & **** & ** & $* * *$ & *** & $* * *$ & $* * *$ & **** & **** & $* * *$ & $* * *$ & $* * *$ \\
\hline $\mathrm{T} \times \mathrm{L}$ & **** & NS & NS & $* *$ & $* * *$ & $* *$ & $* *$ & $* * *$ & $* * *$ & $* * *$ & $* * *$ & $* * *$ \\
\hline $\mathrm{cv}(\%)$ & 6.4 & 6.2 & 4.2 & 5.0 & 4.5 & 5.5 & 2.9 & 2.2 & 1.4 & 2.8 & 2.0 & 1.8 \\
\hline
\end{tabular}

${ }^{2}$ DAT $=$ days after traffic treatment.

${ }^{\mathrm{y}} \mathrm{FL}=$ full sunlight;

${ }^{x}$ AMS = morning shade; PMS = afternoon shade; WD = wear device; WSC = wear plus soil compaction.

"Letters indicate differences for means in a column and within one of analysis group at a given day of treatment based on a adjusted LSD test $(P<0.05)$.

Ns, ***,**,*Nonsignificant or significant at $P<0.001,0.01$ or 0.05 , respectively.

of WD with PMS (average 9\% higher NDVI, $3 \%$ higher CWBI, and $12 \%$ lower stress index). Compared to WSC with PMS, higher NDVI, CWBI, and lower stress index were observed in WSC with AMS from 7 to 14 DAT in Study 1, but not in Study 2, except for CWBI at 14 DAT (average 13\% higher NDVI, 4\% higher CWBI, and $16 \%$ lower stress index).

\section{Discussion}

Relative to FL, AMS and PMS light regimes adversely affected turf color and density (Table 1), degree of traffic injury (Table 2), and canopy reflectance indices (Table 3), as is noted by comparing light treatments across traffic treatments. Due to limitations on the number of paired comparisons allowed, FL was not statistically compared to AMS and PMS under no-traffic conditions. However, observation of data (FL, AMS, and PMS under no-traffics) suggested that turf performances were similar, with the greatest differences occurring late in the study (DAT 14, Study 2). The results indicated that in the absence of traffic, $\approx 90 \%$ shade up to $5 \mathrm{~h}$ in the morning or in the afternoon did not markedly affect turf quality in seashore paspalum. Bell and Danneberger (1999) reported similar turf performance after $6 \mathrm{~h}$ of AMS and PMS in creeping bentgrass under shadecloth. The results suggested that temporary shade during a day might not be a problem to turfgrass growth.

When traffic was imposed, differences in turf color, density, and canopy reflectance indices of FL vs. AMS and PMS light regimes were more pronounced. The significant traffic $\times$ light interaction on most dates supported this observation. Both AMS and PMS with traffic

Table 2. Visual shoot tissue injury (\%) of grass affected by shade and traffic stresses during Studies 1 and 2 .

\begin{tabular}{|c|c|c|c|c|c|c|}
\hline \multirow[b]{2}{*}{ Treatments/contrasts } & \multicolumn{3}{|c|}{ Study 1} & \multicolumn{3}{|c|}{ Study 2} \\
\hline & $1 \mathrm{DAT}^{2}$ & 7 DAT & $14 \mathrm{DAT}$ & $1 \mathrm{DAT}$ & 7 DAT & $14 \mathrm{DAT}$ \\
\hline$\overline{\text { FL, no-traffic (control) })^{y}}$ & 0 & 0 & 0 & 0 & 0 & 0 \\
\hline \multicolumn{7}{|c|}{ Mean separation ${ }^{x}$} \\
\hline \multicolumn{7}{|l|}{ Across traffic } \\
\hline FL & $42 b^{w}$ & $12 \mathrm{c}$ & $7 \mathrm{~b}$ & $38 \mathrm{~b}$ & $24 \mathrm{~b}$ & $6 \mathrm{~b}$ \\
\hline AMS & $48 \mathrm{a}$ & $33 \mathrm{~b}$ & $12 \mathrm{a}$ & $43 \mathrm{a}$ & $31 \mathrm{a}$ & $10 \mathrm{a}$ \\
\hline PMS & $50 \mathrm{a}$ & $40 \mathrm{a}$ & $14 \mathrm{a}$ & $44 \mathrm{a}$ & $31 \mathrm{a}$ & $11 \mathrm{a}$ \\
\hline \multicolumn{7}{|l|}{ Across light } \\
\hline Non & $0 \mathrm{~b}$ & $0 \mathrm{~b}$ & $0 \mathrm{c}$ & $0 \mathrm{c}$ & $0 \mathrm{~b}$ & $0 \mathrm{c}$ \\
\hline WD & $71 \mathrm{a}$ & $40 \mathrm{a}$ & $12 \mathrm{~b}$ & $68 \mathrm{a}$ & $42 \mathrm{a}$ & $11 \mathrm{~b}$ \\
\hline WSC & 69 a & $45 \mathrm{a}$ & $21 \mathrm{a}$ & $58 \mathrm{~b}$ & $43 \mathrm{a}$ & $16 \mathrm{a}$ \\
\hline \multicolumn{7}{|c|}{ Orthogonal comparison } \\
\hline Non + AMS & 0 & 0 & 0 & 0 & 0 & 0 \\
\hline Non + PMS & 0 & 0 & 0 & 0 & 0 & 0 \\
\hline $\mathrm{WD}+\mathrm{AMS}$ & 68 & 43 & 12 & 70 & 42 & 11 \\
\hline WD + PMS & $77^{*}$ & $61^{* *}$ & 12 & 73 & $48^{*}$ & \\
\hline $\mathrm{WSC}+\mathrm{AMS}$ & 75 & 57 & 22 & 60 & 44 & 18 \\
\hline WSC + PMS & 73 & 58 & $27^{*}$ & 60 & $50^{*}$ & 19 \\
\hline \multicolumn{7}{|c|}{ Analysis of variance } \\
\hline Traffic (T) & $* * *$ & $* * *$ & $* * *$ & $* * *$ & $* * *$ & $* * *$ \\
\hline Light (L) & ** & $* * *$ & * & $* * *$ & $* *$ & $* * *$ \\
\hline $\mathrm{T} \times \mathrm{L}$ & $* *$ & $* * *$ & $* *$ & ** & $* *$ & $* *$ \\
\hline $\mathrm{CV}(\%)$ & 8.4 & 19.6 & 41.4 & 5.4 & 12.3 & 19.1 \\
\hline
\end{tabular}

${ }^{2} \mathrm{DAT}=$ days after traffic treatment.

${ }^{y} \mathrm{FL}=$ full sunlight;

${ }^{x}$ AMS = morning shade; $\mathrm{PMS}=$ afternoon shade WD = wear device; $\mathrm{WSC}=$ wear plus soil compaction. "Letters indicate differences for means in a column and within one of analysis group at a given day of treatment based on a adjusted LSD test $(P<0.05)$.

ws, ***,**, Nonsignificant or significant at $P<0.001,0.01$, or 0.05 , respectively.

stresses had slower recovery than FL; this response carried through to the 14 DAT period of recovery (Tables 1,2,3). These data support the belief that grasses subjected to reduced light conditions, even on a temporary basis, are more susceptible to traffic injuries.

During the recovery from traffic injury,
AMS with WD or WSC generally had better turf color and density than that of PMS with WD or WSC within 14 DAT. The results indicated that reduced afternoon sunlight might limit new leaf growth and shoot recovery during 2 weeks for seashore paspalum subjected to wear injury and wear plus soil compaction. 
Table 3. Canopy spectral reflectance of grass affected by shade and traffic stresses during Studies 1 and 2.

\begin{tabular}{|c|c|c|c|c|c|c|c|c|c|c|c|c|}
\hline \multirow{3}{*}{$\begin{array}{l}\text { Treatments/ } \\
\text { contrasts }\end{array}$} & \multicolumn{6}{|c|}{ Study 1} & \multicolumn{6}{|c|}{ Study 2} \\
\hline & \multicolumn{2}{|c|}{$\begin{array}{c}\mathrm{NDVI}^{\mathrm{z}} \\
\end{array}$} & \multicolumn{2}{|c|}{ Stress } & \multicolumn{2}{|c|}{ CWBI } & \multicolumn{2}{|c|}{ NDVI } & \multicolumn{2}{|c|}{ Stress } & \multicolumn{2}{|c|}{ CWBI } \\
\hline & $7 \mathrm{DAT}^{\mathrm{y}}$ & 14 DAT & 7 DAT & 14 DAT & 7 DAT & 14 DAT & 7 DAT & 14 DAT & 7 DAT & 14 DAT & 7 DAT & 14 DAT \\
\hline $\begin{array}{l}\overline{\text { FL, no-traffic }} \\
\quad(\text { control })^{\mathrm{x}}\end{array}$ & 0.64 & 0.65 & 0.22 & 0.21 & 1.07 & 1.07 & 0.59 & 0.62 & 0.24 & 0.23 & 1.08 & 1.07 \\
\hline & & & & & Mean s & aration $^{w}$ & & & & & & \\
\hline $\begin{array}{c}\text { Across traffic } \\
\text { FL } \\
\text { AMS } \\
\text { PMS }\end{array}$ & $\begin{array}{l}0.59 \mathrm{a}^{\mathrm{v}} \\
0.58 \mathrm{a} \\
0.53 \mathrm{~b}\end{array}$ & $\begin{array}{l}0.65 \mathrm{a} \\
0.64 \mathrm{a} \\
0.57 \mathrm{~b}\end{array}$ & $\begin{array}{l}0.25 \mathrm{~b} \\
0.27 \mathrm{~b} \\
0.30 \mathrm{a}\end{array}$ & $\begin{array}{l}0.21 \mathrm{~b} \\
0.22 \mathrm{~b} \\
0.27 \mathrm{a}\end{array}$ & $\begin{array}{l}1.05 \mathrm{a} \\
1.03 \mathrm{a} \\
1.00 \mathrm{~b}\end{array}$ & $\begin{array}{l}1.06 \mathrm{a} \\
1.04 \mathrm{~b} \\
1.02 \mathrm{c}\end{array}$ & $\begin{array}{l}0.57 \mathrm{a} \\
0.56 \mathrm{ab} \\
0.53 \mathrm{~b}\end{array}$ & $\begin{array}{l}0.61 \mathrm{a} \\
0.61 \mathrm{a} \\
0.58 \mathrm{~b}\end{array}$ & $\begin{array}{l}0.26 \mathrm{~b} \\
0.28 \mathrm{~b} \\
0.30 \mathrm{a}\end{array}$ & $\begin{array}{l}0.23 \mathrm{~b} \\
0.24 \mathrm{~b} \\
0.27 \mathrm{a}\end{array}$ & $\begin{array}{l}1.06 \mathrm{a} \\
1.04 \mathrm{~b} \\
1.02 \mathrm{c}\end{array}$ & $\begin{array}{l}1.06 \mathrm{a} \\
1.06 \mathrm{a} \\
1.03 \mathrm{~b}\end{array}$ \\
\hline $\begin{array}{c}\text { Across light } \\
\text { Non } \\
\text { WD } \\
\text { WSC }\end{array}$ & $\begin{array}{l}0.64 \mathrm{a} \\
0.56 \mathrm{~b} \\
0.50 \mathrm{c}\end{array}$ & $\begin{array}{l}0.64 \mathrm{a} \\
0.63 \mathrm{a} \\
0.57 \mathrm{~b}\end{array}$ & $\begin{array}{l}0.22 \mathrm{c} \\
0.28 \mathrm{~b} \\
0.32 \mathrm{a}\end{array}$ & $\begin{array}{l}0.22 \mathrm{~b} \\
0.23 \mathrm{~b} \\
0.26 \mathrm{a}\end{array}$ & $\begin{array}{l}1.05 \mathrm{a} \\
1.02 \mathrm{~b} \\
1.00 \mathrm{c}\end{array}$ & $\begin{array}{l}1.06 \mathrm{a} \\
1.05 \mathrm{a} \\
1.03 \mathrm{~b}\end{array}$ & $\begin{array}{l}0.60 \mathrm{a} \\
0.56 \mathrm{~b} \\
0.51 \mathrm{c}\end{array}$ & $\begin{array}{l}0.61 \mathrm{a} \\
0.61 \mathrm{a} \\
0.59 \mathrm{~b}\end{array}$ & $\begin{array}{l}0.25 \mathrm{c} \\
0.28 \mathrm{~b} \\
0.32 \mathrm{a}\end{array}$ & $\begin{array}{l}0.24 \mathrm{a} \\
0.24 \mathrm{a} \\
0.26 \mathrm{a}\end{array}$ & $\begin{array}{l}1.06 \mathrm{a} \\
1.03 \mathrm{~b} \\
1.03 \mathrm{~b}\end{array}$ & $\begin{array}{l}1.06 \mathrm{a} \\
1.04 \mathrm{~b} \\
1.04\end{array}$ \\
\hline $\begin{array}{l}\text { Non + AMS } \\
\text { Non + PMS }\end{array}$ & $\begin{array}{l}0.64 \\
0.63\end{array}$ & $\begin{array}{l}0.65 \\
0.63\end{array}$ & $\begin{array}{l}0.23 \\
0.22\end{array}$ & $\begin{array}{l}0.21 \\
0.22\end{array}$ & $\begin{array}{c}\text { Prthogono } \\
1.04 \\
1.05\end{array}$ & $\begin{array}{c}\text { comparis } \\
1.05 \\
1.05\end{array}$ & $\begin{array}{l}0.61 \\
0.58\end{array}$ & $\begin{array}{l}0.62 \\
0.58^{*}\end{array}$ & $\begin{array}{l}0.25 \\
0.27\end{array}$ & $\begin{array}{l}0.24 \\
0.27^{*}\end{array}$ & $\begin{array}{l}1.06 \\
1.04\end{array}$ & $\begin{array}{l}1.07 \\
1.03^{* * *}\end{array}$ \\
\hline $\begin{array}{l}\text { WD + AMS } \\
\text { WD + PMS }\end{array}$ & $\begin{array}{l}0.59 \\
0.53^{*}\end{array}$ & $\begin{array}{l}0.64 \\
0.61\end{array}$ & $\begin{array}{l}0.27 \\
0.30\end{array}$ & $\begin{array}{l}0.22 \\
0.24\end{array}$ & $\begin{array}{l}1.04 \\
1.00^{* * *}\end{array}$ & $\begin{array}{l}1.05 \\
1.03\end{array}$ & $\begin{array}{l}0.59 \\
0.53^{*}\end{array}$ & $\begin{array}{l}0.63 \\
0.58^{* *}\end{array}$ & $\begin{array}{l}0.26 \\
0.30^{*}\end{array}$ & $\begin{array}{l}0.23 \\
0.26^{*}\end{array}$ & $\begin{array}{l}1.05 \\
1.01^{* *}\end{array}$ & $\begin{array}{l}1.05 \\
1.03^{*}\end{array}$ \\
\hline $\begin{array}{l}\text { SWC + AMS } \\
\text { SWC + PMS }\end{array}$ & $\begin{array}{l}0.51 \\
0.43^{* *}\end{array}$ & $\begin{array}{l}0.62 \\
0.46^{* * *}\end{array}$ & $\begin{array}{l}0.32 \\
0.37^{* *}\end{array}$ & $\begin{array}{l}0.23 \\
0.34^{* * * *}\end{array}$ & $\begin{array}{l}1.03 \\
0.97^{* * * *}\end{array}$ & $\begin{array}{l}1.06 \\
0.99^{* * *}\end{array}$ & $\begin{array}{l}0.48 \\
0.49\end{array}$ & $\begin{array}{l}0.59 \\
0.57\end{array}$ & $\begin{array}{l}0.34 \\
0.34\end{array}$ & $\begin{array}{l}0.25 \\
0.27\end{array}$ & $\begin{array}{l}1.01 \\
1.02\end{array}$ & $\begin{array}{l}1.05 \\
1.03^{*}\end{array}$ \\
\hline Traffic (T) & $* * *$ & $* * *$ & $* * *$ & $* *$ & $\underset{* * *}{\text { Analysis }}$ & $\begin{array}{c}\text { f variance } \\
\qquad * *\end{array}$ & $* * *$ & $*$ & $* * *$ & NS & $* * *$ & * \\
\hline Light (L) & $* * *$ & $* * *$ & $* * *$ & $* * *$ & $* * *$ & $* * *$ & $*$ & $* * *$ & $* *$ & $* * *$ & $* * *$ & $* * *$ \\
\hline $\mathrm{T} \times \mathrm{L}$ & $* *$ & $* * *$ & $* *$ & $* *$ & $*$ & $* *$ & $*$ & NS & $* *$ & NS & $*$ & NS \\
\hline CV (\%) & 4.8 & 4.2 & 6.8 & 9.6 & 1.3 & 1.1 & 5.3 & 2.8 & 6.8 & 5.7 & 1.2 & 1.1 \\
\hline
\end{tabular}

${ }^{2}$ NDVI, CWBI: highest value = best; stress: lowest values = best. NDVI = normalized difference vegetation index; CWBI = canopy water band index.

'DAT $=$ days after traffic treatment.

${ }^{\mathrm{x}} \mathrm{FL}=$ full sunlight;

"AMS = morning shade; PMS = afternoon shade; $\mathrm{WD}=$ wear device; WSC = wear plus soil compaction.

vetters indicate differences for means in a column and within one of analysis group at a given day of treatment based on a adjusted LSD test $(\mathrm{P}<0.05)$.

Ns, ***,**, Nonsignificant or significant at $P<0.001,0.01$, or 0.05 , respectively.

Bell et al. (2000) found that total PAR (blue + red) was not affected by morning and afternoon periods in full sun; however, the ratios of blue irradiance (B) to photosynthetic photo flux plus far-red photo flux (PPFFR) (B/PPFFR) and B to far red photon flux (FR) (B/FR) were greater in the afternoon. The changes in B/PPFFR and $\mathrm{B} / \mathrm{FR}$ might play a role in better performance of the AMS-grass for recovery from traffic stresses in this study. In addition, AMS may reduce evapotranspiration earlier in the day, resulting in better moisture availability in the afternoon relative to the PMS situation.

Leaf reflectance has been widely used to detect responses of plants to environmental stresses (Carter, 1994; Penuelas et al., 1997a; Trenholm et al., 1999a). Canopy reflectance indices are also correlated with turf quality, color, and density and are related to wear tolerance (Trenholm et al., 1999b). The values of NDVI and stress index generated from leaf or canopy reflectance at visible and infrared ranges further reflected chlorophyll content and stress status (Carter, 1994; Gamon and Surfus, 1999). Higher values of NDVI and a lower stress index were related to better color and density as observed with AMS plus WD compared to PMS with WD. Variations in NDVI and stress index were found between AMS and PMS under WSC treatment in Study 1 (strong indice difference) and Study 2 (no indice difference). This may reflect different weather conditions during recovery.

CWBI, expressed as the ratio of reflectance at 900 and $970 \mathrm{~nm}$, has been used in detecting canopy water status (Penuelas et al., 1997).
Comparisons of CWBI provided insight into traffic injury under shade environments. Consistent with other measurements, AMS with both WD and WSC had higher, better CWBI than that of PMS with WD and WSC. The results indicated a strong link between vegetation water status and turfgrass traffic injury and recovery. In addition, reduction in leaf total cell wall content (i.e., higher cell water content) is one of the most important mechanisms in wear tolerance of seashore paspalum (Trenholm et al., 2000).

Minimal initial injury from a traffic event and rapid recovery of shaded turfgrass from traffic injury are important aspects of tolerating low light plus traffic stresses. Turf color is an important component of turf quality. However, less interaction between light and traffic was found in turf color in this study, indicating that factors other than turf color mainly contributed to severe decrease in overall turf quality under shade plus traffic conditions. Recovery of turf color was also observed more quickly than density, which perhaps was due to rapid new leaf growth underneath the injured tissue or quick recovery of injured leaves in seashore paspalum. Although WSC and WD traffic had similar degrees of initial shoot injury across light levels, the poorer turf density caused by WSC treatment contributed to slower recovery of turf quality overtime, since WSC treatment involved both wear injury and soil compaction (Carrow et al., 2001). Therefore, turf density mainly determined differences in turf quality for shaded grasses under both WD and WSC.
When comparing the magnitude of main treatment effects, traffic treatments caused more damage than the AMS or PMS light treatments. This suggests that management of turfgrass in shady environments and sports fields should be performed to minimize traffic, especially to reduce wear plus soil compaction. This may not be easy to practice in a realistic sports use situation. PMS would be expected to result in somewhat greater injury when the grass is subjected to traffic, compared to AMS. Management practices should give attention to recovery immediately after traffic is imposed, particularly to those grasses grown under afternoon shade.

\section{Literature Cited}

Beard, J.B. 1997. Shade stress and adaptation mechanisms of turfgrasses. Intl. Turfgrass Soc. Res. J. 8:1186-1195.

Bell, G.E. and T.K. Danneberger. 1999. Temporal shade on creeping bentgrass turf. Crop Sci. 39: 1142-1146.

Bell, G.E., T.K. Danneberger, and M.J. Mcmahon. 2000. Spectral irradiance available for turfgrass growth in sun and shade. Crop Sci. 40: 189-195.

Canaway, P.M. 1981. A comparison of real and artificial wear. J. Sports Turf Res. Inst. 57: 108-121.

Carrow, R.N. 1980. Influence of soil compaction on three turfgrass species. Agron. J. 72:1038-1042.

Carrow, R.N. and B.J. Johnson. 1996. Turfgrass wear stress: Effects of golf car and tire design. HortScience 31:968-971.

Carrow, R.N., and A.M. Petrovic. 1992. Effects of traffic on turfgrass. ASA-CSSA-SSSA Turf- 
grass-Agron. Monogr. No. 32. p. 285-330.

Carrow, R.N., R.R. Duncan, J.E. Worley, and R.C. Shearman. 2001. Turfgrass traffic (soil compaction plus wear) simulator: response of Paspalum Vaginatum and Cynodon spp. Intl. Turfgrass Soc. Res. J. 9:253-257.

Carter,G.A. 1994. Ratios of leaf reflectance in narrow wavelength as indicators of plant stress. Intl. J. Remote Sensing 15:697-703.

Cockerham, S.T., V.A. Gibeault, and M. Borgonovo. 1994. Traffic effects on turfgrasses under restricted light. California Turfgrass Cult. 44:1-3.

Duncan, R.R. 1999. Environmentally compatibility of seashore paspalum (saltwater couch) for golf courses and other recreational uses. II. Management protocols. Intl. Turfgrass Soc. Res. J. 8:1230-1239.

Dunn, J.H., D.D. Minner, B.F. Fresenburg, and S.S. Bughrara. 1994. Bermudagrass and cool-season turfgrass mixtures: Responses to simulated traffic. Agron. J. 86:10-16.

Gamon, J.A. and J.S. Surfus. 1999. Assessing leaf pigment content and activity with a reflectometer. New Phytol. 143:105-117.

Penuelas J., R. Isla, I. Filella, and J.L. Araus. 1997a. Visible and near-infrared reflectance assessment of salinity effects on barley. Crop Sci. 37:198-202.

Penuelas, J., J. Pinol, R. Ogaya, and I. Filella. 1997b. Estimation of plant water concentration by the reflectance water index WI (R900/R970). Intl. J. Remote Sensing 18:2863-2868.

Qian, Y. and M.C. Engelke. 1999. Influence of trinexapac-ethyl on Diamond zoysiagrass in a shade environment. Crop Sci. 39:202-208.

SAS Institute, 1987. SAS user's guide: Statistics. 6th ed. SAS Inst., Cary, N.C.

Shearman, R.C. and J.B. Beard. 1975. Turfgrass wear tolerance mechanisms III. Physiological, morphological, and anatomical characteristics associated with turfgrass wear tolerance. Agron. J. 67:215-218.

Shearman, R.C., R.N. Carrow, L.A. Wit, R.R. Duncan, L.E. Trenholm, and J.E. Worley. 2001. Turfgrass traffic simulators: A description of two self-propelled devices simulators wear and compaction stress injury. Intl. Turfgrass Soc. Res. J. 9:347-352.

Stier, J.C. and J.N. Rogers III. 2001. TrinexapacEthyl and iron effects on Supina and Kentucky bluegrass under low irradiance. Crop Sci. 41: 457-465.

Trenholm, L.E., R.N. Carrow, and R.R. Duncan. 1999a. Relationship of multispectral radiometry data to qualitative data in turfgrass research. Crop Sci. 39: 763-769.

Trenholm, L.E., R.R. Duncan, and R.N. Carrow. 1999b. Wear tolerance, shoot performance, and spectral reflectance of seashore paspalum and bermudagrass. Crop Sci. 39: 1147-1152.

Trenholm, L.E., R.N. Carrow, and R.R. Duncan. 2000. Mechanisms of wear tolerance in seashore paspalum and bermudagrass. Crop Sci. 40: 1350-1357.

Van Huylenbroeck, J.M., and E.Van Bockstaele. 2001. Effects of shade on photosynthetic capacity and growth of turfgrass species. Intl. Turfgrass Soc. Res. J. 9: 353-359. 